\title{
SURVIVOR BENEFITS AND THE GENDER TAX GAP IN PUBlic PENSION SCHEMES: OBSERVATIONS FROM GERMANY
}

\author{
MARTIN WERDING
}

CESIFO WORKING PAPER NO. 1596

CATEgory 3: SOCIAL PROTECTION

NOVEMBER 2005

An electronic version of the paper may be downloaded

- from the SSRN website:

wWw.SSRN.com

- from the CESifo website: www.CESifo-group.de 


\title{
SURVIVOR BENEFITS AND THE GENDER TAX GAP IN PUBLIC PENSION SCHEMES: OBSERVATIONS FROM GERMANY
}

\begin{abstract}
Since its inception, the traditional form of providing survivor benefits within public pension schemes has lost much of its legitimacy. As a result of fundamental changes in marriage behaviour and the typical division of labour between married spouses, offering noncontributory benefits of this kind could be seen as inequitable. Since these benefits usually substitute for non-derived pension entitlements based on the surviving spouse's own contributions, they can also lead to incentive effects, especially for married women with some degree of labour-force attachment, that appear to be far from optimal. The present paper highlights this problem referring to institutional details and empirical results related to Germany and shows how it could be resolved by jointly annuitizing a given couple's pension entitlements.
\end{abstract}

JEL Code: H55, J16, J22.

Keywords: public pensions, survivor benefits, female labour supply, optimal taxation.

\author{
Martin Werding \\ Ifo Institute for Economic Research \\ at the University of Munich \\ Poschingerstr. 5 \\ 81679 Munich \\ Germany \\ werding@ifo.de
}

For helpful suggestions and comments, I am grateful to Martin Kolmar and the members of the Social Policy Committee of the Verein für Socialpolitik. All errors that remain are mine. 


\section{Introduction}

Next to old-age and disability pensions, survivor benefits form part of the traditional benefit package provided by most existing public pension schemes. In the German Statutory Pension Scheme, the earliest public pension scheme in the industrialized world, widows' and orphans' pensions were introduced with a small delay (in 1904, while the scheme as such was set up in 1889; see Frerich and Frey 1993). But since the early $20^{\text {th }}$ century, they are a standard type of benefits that spouses and young children who outlive their breadwinners are entitled to receive without any very restrictive qualifying conditions and without the insured individual having paid any other than the regular contributions. Later on, this design has been exported to many other countries. In most cases, for reasons of legal non-discrimination, widowers' pensions have been introduced more recently as an additional category of survivor benefits. ${ }^{1}$

The present paper mainly concentrates on widows' pensions and on the standard case where these are paid to women who have reached, or are close to, their own retirement phase. The problems it is going to highlight are relevant for pensions paid to partners, not children, of an insured individual and they relate to labour supply decisions taken by these partners during earlier stages of their life cycle. Orphans' pensions as well as pensions paid to young mothers who have to take care of small children are thus out of our focus. Also, in spite of legal entitlements that are basically uniform now, the proportion of widowers' pensions to widows' pensions is usually insignificant. ${ }^{2}$ The reasons for this asymmetry are that women are usually younger than their husbands; that, in any case, their life expectancy is significantly longer; and that their husbands are still typically acting as primary earners, building up own pension entitlements by which their claims on widowers' pensions are reduced and often fall to zero, even if the relevant contingency arises.

Over the last decades, there has nonetheless been a substantial change in the division of labour between women and men within a given household, with a continuous increase in female labour-force participation and a notable reduction in the gender wage gap observed earlier on. As a result of these changes that are common across most industrialized countries, providing special benefits for surviving spouses has become more and more obsolete. Figure 1 illustrates these trends, comparing labour-force participation rates and wages for females and males in West Germany, as well as their impact on average, non-derived pension entitlements that is becoming effective, with some delay, within the German Statutory Pension Scheme.

\footnotetext{
${ }^{1}$ For an up-to-date survey of relevant rules for the countries of the EU-15, the US, and Switzerland, see Fenge et al. (2003, Section 1.4.4).

$292.7 \%$ of all widows' and widowers' pensions paid out by the German Statutory Pension Scheme effectively accrue to widows, their average monthly amount being about 2.5 times higher than average widowers' benefits; see Verband Deutscher Rentenversicherungsträger (2004).
} 


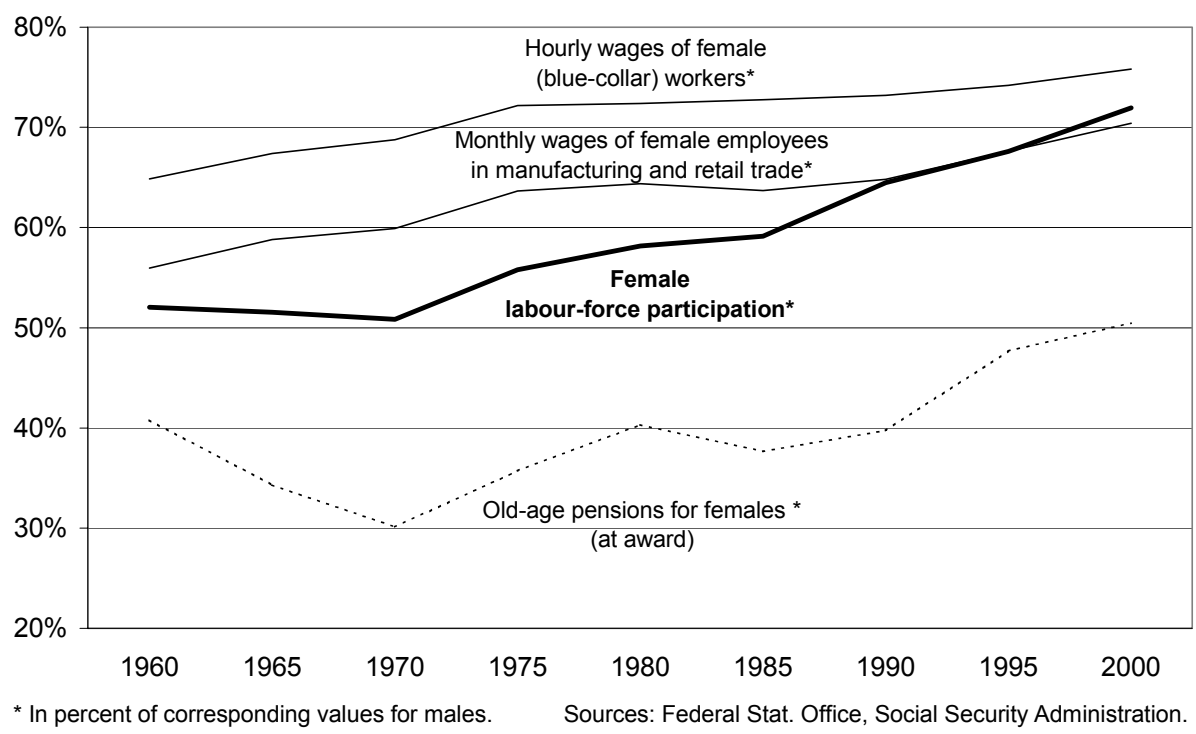

Fig. 1: Labour-force participation, wages and pension benefits of women

(West-Germany, 1960-2000)

In the German debate, the main objections to how survivor benefits are currently being assessed are $(i)$ that they can lead to over-provision in cases of married individuals where both partners have built up some amount of pension entitlements based on own contributions; ( $i i$ ) that they do not really substitute for rules addressing a sufficient level of benefits for parents, especially mothers, who spent a lot of time and other resources on rearing children, thus contributing to the future funding of pay-as-you-go public pension schemes; (iii) that they have ceased to be a fair insurance against the risk of leaving behind dependant family members and have instead become a mechanism for redistributing resources from those who never marry to married couples with wives who are not working.

If the traditional form of providing survivor benefits has come under attack because of its redistributive features, the incentive effects should have become problematic as well. This is what the present paper mainly looks at, concentrating on how pension entitlements typically collected in the German Statutory Pension Scheme affect the work incentives for married females vs males. An important intermediate result is that the "implicit wage tax" that is involved in any unfunded pension scheme is usually higher for married women than for their husbands. Based on a simple theoretical modelling and simulations regarding implicit tax rates in the German public pension scheme, Section 2 explains that this "gender tax gap" is mainly due to the way how, in this scheme, survivor benefits partially off-set the women's individual, non-derived benefit entitlements. ${ }^{3}$

\footnotetext{
${ }^{3}$ If survivor benefits were absent, implicit tax rates falling on women should, ceteris paribus, be lower than those for males. At least, this is what should be expected to result from higher
} 
In the light of empirical estimates regarding the wage elasticity of labour supply for women and men, Section 3 investigates whether this particular tax structure could be in line with the fundamental rules of an optimal taxation of wage earnings. Since the result is negative, Section 4 discusses a possible solution that would make the incentive problem disappear but still provides an option for married couples to secure a level of pension benefits for the surviving spouse which may exceed his or her own, non-derived benefit entitlements. Section 5 concludes.

Note that the considerations made in this paper are not exclusively relevant for Germany only. The specific rules applied in other countries are different from the German ones. In most cases, however, the tax structure that they generate is similar. U.S. Social Security, for instance, with its weaker link between contributions and pension benefits implies that implicit tax rates vary inversely with life-time earnings. This should reduce the difference between tax rates for primary earners and secondary earners, but need not make it disappear. In addition, Social Security offers "spouse benefits" for dependant partners that are payable while the insured individual is still alive. As they also substitute for own benefit entitlements of second earners (on a one-for-one basis), they can strongly increase implicit tax rates for married women when compared to those of their husbands (see, for instance, Blau 1997).

For parallel reasons, even the UK State Pension system, with flat-rate benefits that are only differentiated by the number of qualifying years, involves some elements of an extra-tax for married women. Paying the minimum amount of contributions for a given year to become covered may not make sense for women whose resulting benefit entitlements are too small to become effective in the presence of spouse benefits, which also exist here, and survivor benefits. Only in a pension system where benefits are entirely lump-sum, not even differentiated pro rata temporis, implicit tax rates were always equal to (explicit) contribution rates and, hence, uniform across all members of a given age cohort, including married spouses (while benefits are a pure transfer).

\section{Survivor benefits and the tax implied in pub- lic pay-as-you-go pensions}

In a stylized model that concentrates on what is essential for the following discussion, average households are considered to be composed of two individuals (married to each other), one a male $(m)$ and the other a female $(f)$. The two types of individuals are differentiated by their life expectancy while in retirement. In each case, the expected lenght of the retirement period is measured as a fraction $\alpha$ of the (fixed) length of the active period of life. It is assumed that $\alpha^{f}>\alpha^{m}$, with $0<\alpha^{i}<1, i \in\{m, f\}$. In other words, the contingent life expectancy of a woman entering retirement is higher than that of her hus-

life expectancy of females if contribution rates are uniform and annual benefits are assessed in a uniform way. 
band. For simplicity, mortality risks while still being active are ignored here; differences between the two spouses regarding their age or the timing of their retirement could be reflected, up to a point, in the differentiation of $\alpha$.

In the literature, several approaches have been suggested to model labour supply and other decisions taken by married partners ( $c f$. Killingsworth 1983; Killingsworth and Heckman 1986; Blundell and MaCurdy 1999). So far, evidence regarding the empirical content of all the competing models is mixed (ibid.). However, the problem addressed in this paper is relevant, more or less, under any of the existing approaches. We will therefore pay attention to what we consider the two limiting cases, viz. a "male-chauvinist" model of household labour supply (Bowen and Finegan 1969) and a "unitary" model in which labour supply is based on joint utility maximization of the two spouses (Ashenfelter and Heckman 1974). As far as labour supply is concerned, the large variety of "collective" or "interactive" approaches to modelling household-level decisions (see, e.g., Chiappori 1992; Ott 1992; or Browning et al. 1994) can simply be taken to represent intermediate solutions between these polar cases. Beyond that, we do not bother to give the multi-dimensional intra-household decision problem much structure.

\subsection{The "male-chauvinist" model}

In this type of model, the two spouses are assumed to maximize their utilities independently, with relatively fixed, traditional role assignments. In other words, the husband moves first in terms of his labour-supply decision, while the wife chooses her labour supply taking as given the husband's labour supply and net life-time earnings. Household labour supply can therefore be analyzed by stepping into the shoes of a married woman who is faced with the following problem:

$$
\begin{aligned}
\max _{c, z, l^{f}} u_{t}^{f} & =u\left(c_{t}^{f}, z_{t+1}^{f}, 1-l_{t}^{f}\right) \\
\text { s.t. } \quad c_{t}^{f}+\frac{z_{t+1}^{f}}{1+r_{t+1}} & =\left(1-\tau_{t}\right)\left(W_{t}^{m} l_{t}^{m}+W_{t}^{f} l_{t}^{f}\right)+\frac{p_{t+1}^{m}+p_{t+1}^{f}}{1+r_{t+1}}
\end{aligned}
$$

Here, the wife's utility is a function of goods consumed during her active life span and in the retirement period, $c_{t}^{f}$ and $z_{t+1}^{f}$, respectively, ${ }^{4}$ and leisure consumed while she is still active, $1-l_{t}^{f}$. The intertemporal budget constraint states that goods consumption in periods $t$ and $t+1$ must be nourished from net life-time earnings of both spouses that are determined by their gross wage rates, $W_{t}^{i}$, labour supply, $l_{t}^{i}$, the contribution rate of the pension scheme, $\tau_{t}$, and pension benefits accruing in the retirement period, $p_{t+1}^{i} .{ }^{5}$ From the wife's perspective, the husband represents something like a fixed asset and his net life-time earnings

\footnotetext{
${ }^{4}$ Assuming that the wife effectively controls the household's goods consumption, variables $c$ and $z$ could also be taken to represent aggregates across the household.

${ }^{5}$ To make period- $t+1$ amounts of money comparable to those in period $t$, they are discounted by the interest factor $1+r_{t+1}$.
} 
(or an exogenously determined share of these) are equivalent to some kind of non-labour income.

If we want to look at individual labour-supply decisions that are taken sequentially by each partner - the husband taking the lead - and see how these can be influenced by the pension system, we have to spell out more fully how benefit entitlements are defined. In a pay-as-you-go pension scheme that strongly links benefits to earlier contributions, such as the German Statutory Pension Scheme, benefits can be determined based on a factor reflecting the internal rate of return on contributions, $1+\rho_{t+1}$, which should be uniform across insured individuals belonging to the same age cohort. In addition, what matters for the size of $p_{t+1}^{i}$ is $(i)$ the length of the retirement period, hence life expectancy $\alpha^{i}$; (ii) the definition of survivor benefits that are derived from benefit entitlements of the partner faced with shorter life expectancy; and (iii) the rules that govern what happens when own, non-derived pension entitlements for the surviving partner and survivor benefits coincide. In the following, we assume the relevant structure of benefits to be as follows:

$$
\begin{gathered}
p_{t+1}^{m}=\left(1+\rho_{t+1}\right)\left(\alpha^{m}+\left(\alpha^{f}-\alpha^{m}\right) \gamma\right) \tau_{t} W_{t}^{m} l_{t}^{m} \\
p_{t+1}^{f}=\left\{\begin{array}{l}
\text { case 1: }\left(1+\rho_{t+1}\right) \alpha^{m} \tau_{t} W_{t}^{f} l_{t}^{f} \\
\text { case 2: }\left(1+\rho_{t+1}\right) \tau_{t}\left(\alpha^{m} W_{t}^{f} l_{t}^{f}+\left(\alpha^{f}-\alpha^{m}\right)\left(W_{t}^{f} l_{t}^{f}-\gamma W_{t}^{m} l_{t}^{m}\right)\right)
\end{array}\right.
\end{gathered}
$$

Pension benefits that can be attributed to the husband's contributions, $p_{t+1}^{m}$, include his own old-age pension benefits paid out in period $\alpha^{m}$ as well as derived survivor benefits paid for another period $\alpha^{f}-\alpha^{m}$. The latter are defined as a fraction of $0<\gamma<1$ of the original benefits, in line with the German system where current rules set a corresponding factor at 0.55. As long as the husband is still alive, his wife is entitled to receive old-age pension benefits that are only linked to her own contributions. Once she is widowed, however, her own benefit entitlements are reduced against survivor benefits that are also becoming effective. The one-for-one reduction that is assumed in (3) overstates the actual rules applied in Germany, ${ }^{6}$ but the results are qualitatively unaffected by this simplification.

However, we need to distinguish between two cases now: If the widow's own benefit entitlements turn out to be smaller than the survivor benefits included in (2), the former are effectively terminated in sub-period $\alpha^{f}-\alpha^{m}$ ("case 1": $W_{t}^{f} l_{t}^{f}<\gamma W_{t}^{m} l_{t}^{m}$, with the limiting case of a women who never worked in the labour market, such that $W_{t}^{f} l_{t}^{f}=0$ ); if own benefit entitlements exceed the amount of survivor benefits, it is only the difference that matters ("case 2": $\left.W_{t}^{f} l_{t}^{f}>\gamma W_{t}^{m} l_{t}^{m}\right)$.

Using (2) and (3) to determine effective net wage rates $w_{t}^{i}$ for both spouses, taking into account not only contributions paid to the pension scheme but also

\footnotetext{
${ }^{6}$ Currently, the German pension law defines a threshold amount of own benefit entitlements that are exempted from the reduction. This threshold amount is differentiated between West and East Germany and increases with the number of children the survivor has raised. Higher benefits are reduced by $40 \%$ per Euro of survivor benefits that the individual is entitled to receive as well.
} 
benefit entitlements that are linked to these contributions, leads to:

$$
\begin{gathered}
w_{t}^{m}=\left(1-\tau_{t}\left(1-\left(\alpha^{m}+\left(\alpha^{f}-\alpha^{m}\right) \gamma\right) \frac{1+\rho_{t+1}}{1+r_{t+1}}\right)\right) W_{t}^{m} \\
w_{t}^{f_{1}}=\left(1-\tau_{t}\left(1-\alpha^{m} \frac{1+\rho_{t+1}}{1+r_{t+1}}\right)\right) W_{t}^{f} \\
w_{t}^{f_{2}}=\left(1-\tau_{t}\left(1-\left(\alpha^{m}+\left(\alpha^{f}-\alpha^{m}\right)\left(1-\gamma \frac{W_{t}^{m} l_{t}^{m}}{W_{t}^{f} l_{t}^{f}}\right)\right) \frac{1+\rho_{t+1}}{1+r_{t+1}}\right)\right) W_{t}^{f}
\end{gathered}
$$

The terms $\tau_{t}(1-\ldots)$ included in (4) to (6) represent differentiated rates of an "implicit" (wage) tax that is next to automatically imposed on insured individuals through their mandatory participation in a pay-as-you-go pension scheme. ${ }^{7}$ In a system with earnings-related benefits, these tax rates are positive, but smaller than contribution rates, mainly because the internal rate of return, $\rho_{t+1}$, is usually smaller than the interest rate, $r_{t+1}$, used for discounting. The specific formulae obtained here incorporate the system of survivor benefits sketched before. In the following, we will call these implicit tax rates - in the order of their appearance in the above equations $-\vartheta_{t}^{m}, \vartheta_{t}^{f_{1}}$ and $\vartheta_{t}^{f_{2}}$, respectively.

Case 1 (" $f_{1}$ ") implies that the widow's own benefit entitlements become immaterial during the period of survivorhood. For a woman falling in this category, the implicit tax rate will therefore be strictly higher than in case 2 $\left(\right.$ " $f_{2}$ "), where individual, non-derived benefit entitlements are not entirely off-set through survivor benefits. In this latter case, the implicit tax rate will decrease more and more, depending on how much the woman's own wage earnings, $W_{t}^{f} l_{t}^{f}$, exceed the amount of $\gamma W_{t}^{m} l_{t}^{m}$ that is relevant for her survivor benefits. For $W_{t}^{f} l_{t}^{f} \rightarrow \infty$, the rate converges to the implicit tax rate for an unmarried woman, the latter being only determined by her life expectancy. ${ }^{8}$

What is more interesting, however, is a comparison between implicit tax rates falling on married women $v s$ men. While what we have just said implies that $\vartheta_{t}^{f_{1}}>\vartheta_{t}^{f_{2}}, \vartheta_{t}^{m}$ will usually be even smaller. It is easy to see that

$$
\vartheta_{t}^{f_{2}} \geq \vartheta_{t}^{m} \quad \text { if } \quad \frac{W_{t}^{f} l_{t}^{f}}{W_{t}^{f} l_{t}^{f}+W_{t}^{m} l_{t}^{m}} \leq \gamma .
$$

In other words, implicit tax rates for married women will always be higher than those for their husbands if the survivor-benefit factor exceeds the women's share in total household income. If $\gamma=0.55$, for instance, $W_{t}^{f} l_{t}^{f}$ would have to be $122 . \overline{2} \%$ of $W_{t}^{m} l_{t}^{m}$ for this condition to become binding. Taking the current

\footnotetext{
${ }^{7}$ For an in-depth discussion of the concept of "implicit taxes" involved in pay-as-you-go public pension schemes, see Fenge and Werding (2003).

${ }^{8}$ In our framework, and assuming that the life expectancy of females is not affected by their marriage status, the effective net wage rate for single females (" $s f$ ") would be given by:

$$
w_{t}^{s f}=\left(1-\tau_{t}\left(1-\alpha^{f} \frac{1+\rho_{t+1}}{1+r_{t+1}}\right)\right) W_{t}^{f}
$$
}


relative female-male wage rates displayed in Figure 1 (75\% to $70 \%)$ as a rough approximation for the ratios of earnings in an average household - still neglecting typical differences in the life-time amount of labour supplied by married women and men that continue to exist - there is considerable leeway before the above condition will be violated in more than a few exceptional cases.

\subsection{The "unitary" model and other approaches}

The case we want to establish against the traditional way of defining survivor benefits appears to be the strongest in the context of the "male-chauvinist" model of labour supply discussed in the previous sub-section. But alternative approaches to modelling labour supply at the household level, where partners actively share their resources based on the individual $w_{t}^{i} \mathrm{~s}$ or where their utility functions are directly linked to each other, lead to differentiated tax schedules that do not fully remove our problem.

As another limiting case, one could assume the two spouses to maximize their utilities in such a way that this can be represented by a "unitary" household utility function and a budget constraint aggregated across the household:

$$
\begin{aligned}
\max _{c, z, l^{m}, l^{f}} u_{t} & =u\left(c_{t}, z_{t+1}, 1-l_{t}^{m}, 1-l_{t}^{f}\right) \\
\text { s.t. } \quad c_{t}+\frac{z_{t+1}}{1+r_{t+1}} & =\left(1-\tau_{t}\right)\left(W_{t}^{m} l_{t}^{m}+W_{t}^{f} l_{t}^{f}\right)+\frac{p_{t+1}^{m}+p_{t+1}^{f}}{1+r_{t+1}}
\end{aligned}
$$

Here, changes in the structure of pension benefits that are associated with alternative choices regarding $l^{m}$ and $l^{f}$ directly off-set each other within the couple's joint life-time budget constraint.

In the unitary model, there is no longer an independent definition of $p_{t+1}^{m}$ and $p_{t+1}^{f}$. Instead, the spouses' total benefit entitlements are given by

$$
\begin{aligned}
p_{t+1}^{m}+p_{t+1}^{f}= & \left(1+\rho_{t+1}\right) \tau_{t}\left(\alpha^{m}\left(W_{t}^{m} l_{t}^{m}+W_{t}^{f} l_{t}^{f}\right)+\right. \\
& \left.+\left(\alpha^{f}-\alpha^{m}\right) \max \left(\gamma W_{t}^{m} l_{t}^{m}, W_{t}^{f} l_{t}^{f}\right)\right) .
\end{aligned}
$$

Now, husbands and wives alike are (mutually) affected by the distinction of cases 1 and 2 introduced above. Their effective net wage rates read

$$
\begin{aligned}
w_{t}^{m_{1}} & =\left(1-\tau_{t}\left(1-\left(\alpha^{m}+\left(\alpha^{f}-\alpha^{m}\right) \gamma\right) \frac{1+\rho_{t+1}}{1+r_{t+1}}\right)\right) W_{t}^{m}= \\
= & \left(1-\vartheta_{t}^{m_{1}}\right) W_{t}^{m} \\
w_{t}^{m_{2}} & =\left(1-\tau_{t}\left(1-\alpha^{m} \frac{1+\rho_{t+1}}{1+r_{t+1}}\right)\right) W_{t}^{m}=\left(1-\vartheta_{t}^{m_{2}}\right) W_{t}^{m} \\
w_{t}^{f_{1} \prime} & =\left(1-\tau_{t}\left(1-\alpha^{m} \frac{1+\rho_{t+1}}{1+r_{t+1}}\right)\right) W_{t}^{f}=\left(1-\vartheta_{t}^{f_{1} \prime}\right) W_{t}^{f}
\end{aligned}
$$




$$
w_{t}^{f_{2} \prime}=\left(1-\tau_{t}\left(1-\alpha^{f} \frac{1+\rho_{t+1}}{1+r_{t+1}}\right)\right) W_{t}^{f}=\left(1-\vartheta_{t}^{f_{2} \prime}\right) W_{t}^{f},
$$

with

$$
\vartheta_{t}^{f_{1}^{\prime \prime}}=\vartheta_{t}^{m_{2}}>\vartheta_{t}^{m_{1}}>\vartheta_{t}^{f_{2} \prime} .
$$

Type-1 women (i.e., those with relatively low life-time earnings) are still faced with a higher tax rate than their husbands, while type- 2 women (with earnings that exceed $\gamma W_{t}^{m} l_{t}^{m}$ ) unambiguously bear a lower tax rate than their husbands. Note that $\vartheta_{t}^{f_{1} \prime}=\vartheta_{t}^{f_{1}}$ and $\vartheta_{t}^{m_{1}}=\vartheta_{t}^{m}$, so that the results in terms of implicit tax rates are unaffected by the choice of an alternative modelling approach for case1 couples. In case 2 , however, the differentiated tax rates imposed on married partners effectively align to those arising purely from differences in individual life expectancies.

Speaking more generally and covering, in a rough fashion, a whole range of solutions in between the two extremes we have discussed here, we may therefore state the following. Survivor benefits and the way they interfere with individual, non-derived benefit entitlements tend to increase the implicit tax rates married women are faced with when participating in public pay-as-you-go pension schemes over those imposed on their husbands. If spouses employ a sharing rule for their resources that is contingent on their effective net wages, or if they directly interact with each other when maximizing their utilities, this "gender tax gap" may decrease. In the limit, the implicit tax rate for women can even become smaller than that for their husbands, but this only happens if labour supply and earnings of these women are relatively high.

Now, what do these overall findings tell us? It is not uncommon to think of taxation as the definition of a tax schedule by which indiduals self-select into different categories of tax-payers through their behaviour, effectively picking their tax rate. For instance, this is what happens in a progressive income tax schedule implying higher tax rates for individuals who decide to work longer hours or to acquire higher qualifications. But the case considered here appears to be different. To the extent that the various approaches to modelling married couples' decision-making reflect actual differences in how two partners live together (and not just unresolved ambiguities in applying simple maths to a complex reality), the differentiation of implicit tax rates in public pay-as-you-go pensions is not so much based on individual behaviour that is directly linked to earnings capacities at the individual or household level. Instead, it partly arises from how individuals interact with each other regarding a broad array of household-level decisions. Also, reducing tax rates for married, high-earner women with closer ties to their partners, while increasing those for their husbands, does not appear to be a meaningful (self-)selection strategy that should be built in a well-designed tax schedule. What is most questionable, however, is the fundamental upward trend in implicit tax rates for married women that is due to the conventional way of assessing survivor benefits as such. 


\subsection{Implicit tax rates in the German public pension scheme}

The result that the implicit tax rate involved in public pay-as-you-go pensions is often higher for married women than for their husbands is not an artifact of our simplified model. This can be confirmed by simulations which incorporate the actual rules of how surivor benefits are being assessed in Germany. Amending earlier calculations which focused on implicit tax rates for (male) individuals acting as "principal earners" of their households (Thum and Weizsäcker 2000; Fenge and Werding 2004), ${ }^{9}$ we construct stylized earnings profiles for their wives reflecting on-going changes in average female labour-force participation and in the average gender wage gap for each year covered by the simulations; ${ }^{10}$ we also take into account that married women are usually younger than their husbands and that they tend to live much longer.

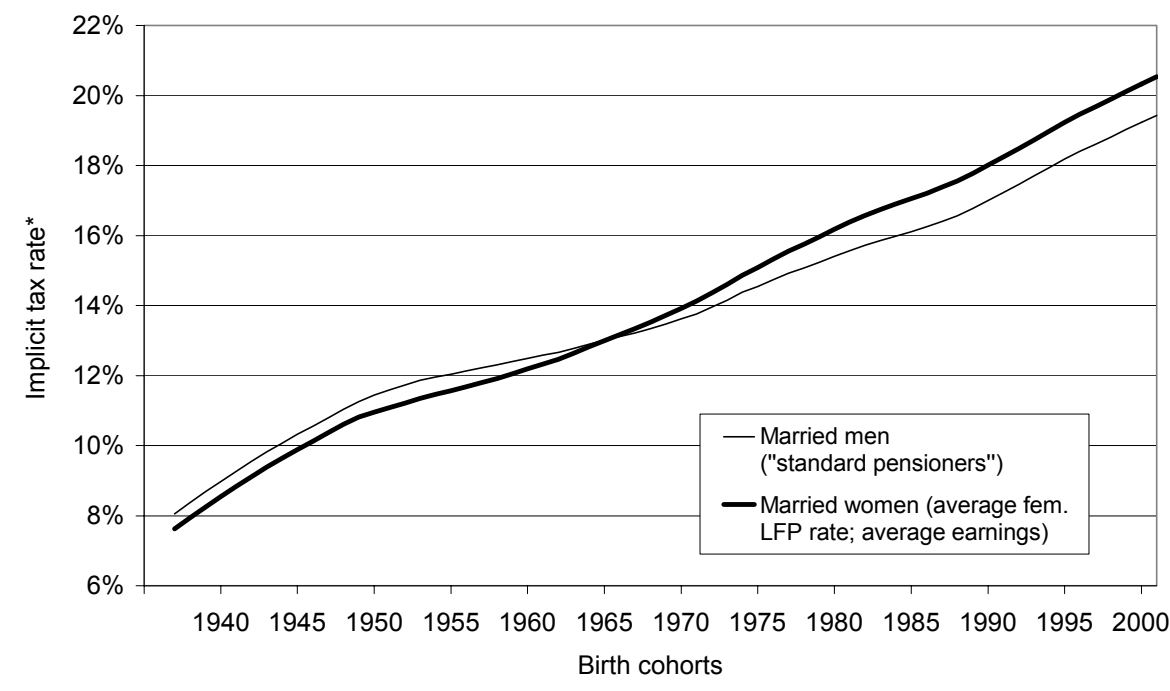

* In percent of life-time gross earnings.

Source: CESifo Pension Model (Version 2004).

Fig. 2: Implicit taxes in the German Statutory Pension Scheme for married individuals (born 1937-2001)

The simulation results exhibited in Figure 2 add a little more detail to our theoretical observations. In particular, they show that, mainly because of their higher life expectancy, implicit tax rates for married women can be lower than those for men as long as their own benefit entitlements are so small that they are exempted, fully or to a large extent, from the reduction against survivor

\footnotetext{
${ }^{9}$ The simulations presented here also take into account the most recent pension reform enacted in 2004.

${ }^{10}$ For the future development of female labour-force participation, we use a scenario that is based on assumptions made for a number of long-term simulations commissioned by the German government (see Werding and Kaltschütz 2005). Regarding the wage gap, we assume that is goes down from a current $25 \%$ (blue-collar workers in manufacturing, see Figure 1) to about $15 \%$ until 2050 .
} 
benefits. But as female labour-force participation increases and the gender wage gap shrinks, the reduction of own benefit entitlements during survivorhood is likely to increase implicit tax rates for married women - in the graph: for average women born starting from 1965 - beyond those for their husbands. In these simulations, ambiguities regarding how to allocate survivor benefits - to husbands or to wives, being off-set by their non-derived benefit entitlements in the latter case - never arise because, throughout, an average woman's own pension benefits are not high enough to escape the marginal reduction against survivor benefits.

\section{Optimal taxation and the gender tax gap}

\subsection{Optimum taxation rules}

It should be noted that the existence of an implicit tax rate per se - even its increasing time trend that shows up in the simulations run for Figure 2 - is not necessarily indicating a fundamental inefficiency involved in pay-asyou-go pension schemes, ${ }^{11}$ even if it is suited to discourage insured individuals, irrespective of their gender, from labour-force participation. What is potentially problematic here, however, is the tax structure derived in the previous section, with tax rates that tend to be systematically higher for married women than for their husbands.

Basically, implicit tax rates are an instrument required for keeping the implicit debt involved in pay-as-you-go pensions - i.e., the present value of outstanding benefits that are linked to all past and present contributions - on a sustainable time path. To avoid that this debt explodes as a percentage of current GDP, the internal rate of return on contributions must fall short of the market rate of interest over the long run. By its demographic and economic fundamentals, $\rho_{t+1}$ is generally restricted to the growth rate of the economy's aggregate payroll, or total taxable wage earnings, such that the above condition should be met. ${ }^{12}$

Considerations of this kind fix the implicit tax which has to be imposed on a given age cohort participating in a pay-as-you-go pension scheme as an absolute amount. In terms of our model - assuming, for simplicity, that all insured individuals are married - this gives us

$$
\vartheta_{t}^{m} W_{t}^{m} l_{t}^{m}+\vartheta_{t}^{f} W_{t}^{f} l_{t}^{f}=\bar{T}_{t} .
$$

\footnotetext{
${ }^{11} \mathrm{Cf}$. the seminal papers by Breyer (1989) and Fenge (1995). Sinn (2000) surveys the entire debate on the efficiency of unfunded pension systems that has been triggered by these contributions. The implications of increasing tax rates for younger age cohorts that are mainly due to current demographic change are discussed in Fenge and Werding (2004).

${ }^{12}$ Considered in a little more detail, the relevant $\rho$ for each cohort that is covered in a pay-as-you-go pension scheme is determined by average participation rates (in our model: $l_{t}^{i}$ and $\left.l_{t+1}^{i}\right)$, average wages $\left(W_{t}^{i}\right.$ and $\left.W_{t+1}^{i}\right)$, and the dependency ratio $\left(\alpha^{m}\right.$ and $\left.\alpha^{f}\right)$, modified by potential changes of the contribution rate $\left(\tau_{t+1}\right.$ against $\left.\tau_{t}\right)$. Note that, as $l^{i}$ is always a cohort-wide average in this calculation, $\rho$ can safely be taken to be given for each insured individual.
} 
It remains an open question, though, which structure of tax rates - here: what $\vartheta_{t}^{i} \mathrm{~s}$ - should ideally be chosen to yield the tax revenue $\bar{T}$.

This question is simply another application of the theory of optimal taxation that investigates the design of tax rates by which a given amount of tax revenue can be levied in such a way that welfare losses imposed on the individuals affected are minimized. Important standard results that are relevant here were already provided by Sandmo $(1974 ; 1987)$ or Atkinson and Stiglitz (1980, ch. 12). An application to implicit taxes involved in public pay-as-you-go pension schemes can be found in Fenge, Uebelmesser and Werding (2002). This paper and its recent up-date, Fenge, Uebelmesser and Werding (2005), also include an empirical assessment on which we can build in the following.

Formally speaking, within the framework of the models considered in Section 2 , we have to find rules defining the optimal structure of $\vartheta_{t}^{m}$ and $\vartheta_{t}^{f}$, assuming that the government maximizes utilities of the individuals affected, taking into account the relevant (household) budget constraint and the additional constraint (13) regarding the tax revenue that is required. The precise approach to be set up differs somewhat between the "male-chauvinist model", where the government's problem is

$$
\begin{gathered}
\max _{\vartheta^{m}, \vartheta^{f}} v_{t}^{f}=v^{f}\left(\vartheta_{t}^{f}, \vartheta_{t}^{m}\right) \\
\text { s.t. } v_{t}^{m}=\bar{v}^{m}\left(\vartheta_{t}^{m}, \vartheta_{t}^{f}\right) \text { and condition (13), }
\end{gathered}
$$

and the "unitary model", where it is

$$
\max _{\vartheta^{m}, \vartheta^{f}} v_{t}=v\left(\vartheta_{t}^{f}, \vartheta_{t}^{m}\right)
$$

s.t. condition (13).

But the final results are basically the same under both approaches. Here, $v^{f}$ and $v$ are the indirect utility functions that can be derived from problems (1) and (7), respectively. In (14), the wife's utility is maximized holding constant the husband's indirect utility $\bar{v}^{m}$ and tax revenue $\bar{T}$, while in (15), $T=\bar{T}$ represents the only constraint.

From the "male-chauvinist model", after a series of conventional re-arrangements, we obtain a variant of the so-called "inverse-elasticities rule" of optimal taxation,

$$
\frac{\vartheta^{f}}{1-\vartheta^{f}}=\frac{\varepsilon^{m}}{\varepsilon^{f}} \frac{\vartheta^{m}}{1-\vartheta^{m}} .
$$

According to condition (16), implicit tax rates for married women, $\vartheta^{f}$, should be higher than those for men, $\vartheta^{m},{ }^{13}$ if the (compensated) wage elasticity of female labour supply, $\varepsilon^{f}$, is lower than the corresponding value for males, $\varepsilon^{m}$, and vice versa. In other words, to limit efficiency losses arising from laboursupply responses, the tax rate imposed on the partner whose labour supply is

\footnotetext{
${ }^{13}$ The transformation to $\vartheta^{i} /\left(1-\vartheta^{i}\right)$ simply relates the tax rate to net earnings, expressing it as a proportional surcharge on these.
} 
more elastic should always be lower than the tax rate for the partner whose labour supply is relatively inelastic.

From the "unitary model", imposing no further restrictions, notably with respect to the form of the utility function, we first obtain a variant of the "Ramsey rule", one of the most fundamental optimum-taxation rules,

$$
\frac{\vartheta^{f}}{1-\vartheta^{f}}=\frac{\varepsilon^{m m}-\varepsilon^{f m}}{\varepsilon^{f f}-\varepsilon^{m f}} \frac{\vartheta^{m}}{1-\vartheta^{m}} .
$$

Condition (17) states, again, that $\vartheta^{f}$ should be higher than $\vartheta^{m}$ if the women's labour supply is less elastic than that of their husbands, and if this relation between "own-price effects" (where the wage elasticity is evaluated with respect to one's own wages, indexed $i i$ ) is not turned over through a highly inverse relation of "cross-price effects", $\varepsilon^{i j}$, with $i, j \in\{m, f\}, i \neq j$ (measuring the elasticity of labour supply with respect to the spouse's wage). ${ }^{14}$ Assuming, in a common simplification, that household utility (7) is fully separable regarding the labour-supply decisions of each partner, so that cross-price elasticities are zero, (17) simplifies to (16). Again, it is only the ratio of (own-)wage elasticities, $\varepsilon^{m}$ and $\varepsilon^{f}$, that determines the optimal tax structure.

\subsection{The empirical side}

Theoretical considerations alone are not suited to clarify what these optimaltaxation rules actually imply for our problem. It is ultimately an empirical question whose labour supply is typically more elastic with respect to net wages, hence wage taxation: that of married women or of their husbands. Exploring a related, yet differing, subject - namely the question of optimal time-profiles of implicit tax rates over individual life cycles (with more than just one active period) - Fenge, Uebelmesser and Werding (2002; 2005) come up with parallel assessments for the labour supply elasticities of married females and males. Their results are thus also of high interest in the current context.

The analysis of labour supply of German males and (married) females conducted in Fenge, Uebelmesser and Werding (2005) is based on data collected through the "German Socio-Economic Panel (GSOEP)" between 1991 and 2002. Self-employed individuals and civil servants are excluded from the sample as, under current rules, they are exempted from mandatory membership in the German Statutory Pension Scheme. Differentiated by gender, the data are pooled to form two sub-samples of "young" and "old" working-age individuals (aged 20-39 and 40-59, respectively). For the purpose of the present paper, this allows for a rough, but meaningful, control for potential cohort effects that may be present especially in female labour supply decisions. Labour supply is defined in terms of decisions on working hours, assuming that the more fundamental

\footnotetext{
${ }^{14}$ Taken in isolation, these cross-price effects have the following impact: implicit tax rates for females should be higher than those for males if the compensated elasticity of labour supply of women with respect to their husbands' wages is lower than the "cross-wage" elasticity of labour supply of men - and vice versa.
} 
decision to participate in the labour market will often be influenced by other considerations - rigidities in the length of certain training periods for younger individuals, the supply of child-care facilities for females, options to exit from the labour market and retire early for older workers, etc. The econometric estimates are based on the standard two-stage procedure suggested by Heckman (1979), where first a (gross) wage equation is estimated to impute wages for those who are not actually working, then a Tobit model (after Tobin 1958) for the unbiased labour supply function based on changes in net earnings. ${ }^{15}$

Building on the coefficients of these estimates - those for the net wage associated with an extra-hour of work and for other household income - one can calculate the compensated wage elasticities of labour supply through a Slutsky decomposition of observable, uncompensated wage elasticities. ${ }^{16}$ Table 1 summarizes the main results, comparing wage elasticities of labour supply for married females and males and confronting them with average implicit tax rates for "young" (" $y$ ") and "old" ( " $o$ ") individuals of working age that can be derived from the simulations for Figure 2.

Table 1: The structure of wage elasticities and implicit taxes for married females and males

\begin{tabular}{lll}
\hline \hline & Wage elasticities & Implicit taxes \\
\hline a) "young" individuals (aged 20-39) & \\
Married females: & $\varepsilon_{y}^{f}=0.53 * *$ & $\vartheta_{y}^{f}=13.9 \%$ \\
Males: & $\varepsilon_{y}^{m}=0.01$ & $\vartheta_{y}^{m}=13.6 \%$ \\
& $\Rightarrow \frac{\varepsilon_{y}^{m}}{\varepsilon_{y}^{f}}=0.02 ;$ & $\frac{\vartheta_{y}^{f}}{1-\vartheta_{y}^{f}} \frac{1-\vartheta_{y}^{m}}{\vartheta_{y}^{m}}=1.02$ \\
& \\
\hline b) "old" individuals (aged 40-59) & $\vartheta_{o}^{f}=9.6 \%$ \\
Married females: & $\varepsilon_{o}^{f}=0.57 * *$ \\
Males: & $\varepsilon_{o}^{m}=0.22 * *$ & $\vartheta_{o}^{m}=9.1 \%$ \\
& $\Rightarrow \frac{\varepsilon_{o}^{m}}{\varepsilon_{o}^{f}}=0.38 ;$ & $\frac{\vartheta_{o}^{f}}{1-\vartheta_{o}^{f}} \frac{1-\vartheta_{o}^{m}}{\vartheta_{o}^{m}}=1.06$ \\
\hline ** denotes significance at a 5-percent level (assessed using a \\
bootstrapping technique with 200 re-samplings). \\
\hline Source: Fenge, Uebelmesser and Werding (2005, Tables 3 and 6).
\end{tabular}

It turns out that, in both age categories, labour supply of married women is much more elastic than that of men of the same age. This is most apparent for young individuals aged 20-39, where male labour supply appears to be virtually

\footnotetext{
${ }^{15}$ For a comprehensive description of the data set and the methods applied, together with a fuller documentation of the results, see Fenge, Uebelmesser and Werding (2005, Sections 4 and 5).

${ }^{16}$ See Fenge, Uebelmesser and Werding (2005, Section 6).
} 
non-responsive to wages. For older individuals aged $40-59$, the wage elasticity of male labour supply increases a lot more against the parallel figure for the young than it does in the case of married women. Yet, it remains well below the wage elasticity of females of the same age. All in all, the basic result that labour supply decisions of women are much more responsive to wages than those of men neither appears to be mainly driven by cohort effects nor by life-cycle effects. ${ }^{17}$ Moreover, it is a consistent finding in a multitude of earlier studies covering Germany and other industrialized countries. ${ }^{18}$

Table 1 also shows that, for the birth cohorts and the time period actually covered through the estimates, implicit tax rates involved in the German Statutory Pension Scheme are indeed a little higher for women than for males in the same age categories. As a result, the ratio of the relevant tax rates (per net earnings) for females vs males is far from what would appear to be optimal to take care of the huge differences in labour-supply reactions. In the case of younger individuals, this ratio would have to be adjusted by a factor of less than $1 / 50$, in the case of older individuals by a factor of about $1 / 3$, in order to bring it in line with the simple inverse-elasticities rule (16).

It might effectively over-burden the results presented here to derive an "optimal" structure of $\vartheta^{i} \mathrm{~s}$ in a quantitatively exact fashion. For this kind of purpose, the empirical design is certainly a bit too rough, neglecting inter alia the slightly differing implications of different approaches to modelling householdlevel decisions. (For instance, cross-wage elasticities of each partner's labour supply that could differ from zero are neglected.) Furthermore, we only look at implicit taxes involved in the pension system, not at other taxes imposed on wage earnings. (Note, however, that the German "splitting" approach to jointly taxing a married couple's income also implies a tendency towards higher tax rates for second earners - mostly women - than for typical breadwinnermales; see Zameck 1997). What the results should be taken to indicate is that the gender-specific structure of implicit taxes involved in pay-as-you-go pension schemes most likely violates fundamental rules of optimal taxation and that this is mainly a by-product of how survivor benefits interact with the survivor's own, non-derived pension entitlements. As a consequence, implicit tax rates imposed on married women should be reduced below the comparable tax rates for men - only, we would possibly over-state our case if we wanted to say by how much.

\footnotetext{
${ }^{17}$ This is largely confirmed by a series of more differentiated estimates for sub-groups of 5 age cohorts each that are also reported in Fenge, Uebelmesser and Werding (2005, Figure 4 and Table 5).

${ }^{18}$ The estimates provided by Franz (1985), Strøm and Wagenhals (1991) or Untiedt (1992) focus on female labour supply; they support that wage elasticities of women are considerably high, but do not allow for comparisons with those of men. The studies by Buslei and Steiner (1999), Kaltenborn (2000) or Steiner and Wrohlich (2004) clearly confirm our results. For a comparative survey of parallel results obtained for other countries, see Blundell and MaCurdy (1999, Sections 6.8, 7.3 and 8.4).
} 


\section{Options for reforming survivor benefits}

The problems highlighted in this paper are mainly due to the fact that survivor benefits usually substitute for pension entitlements that are based on the survivor's own contributions. If, under current socio-economic conditions, survivor benefits are also less and less justified by distributional objectives, abolishing them might appear to be a natural solution. ${ }^{19}$ So far, the only industrialized country that has moved in this direction appears to be Sweden (in 1990), the main reason being that high labour-force participation rates of (married) women in this country had made special provisions seemingly redundant. ${ }^{20}$

Here, we will take up this idea when addressing the policy implications of our considerations ("step 1") and amend it with a second feature that is also inspired by an element of the current Swedish pension system: joint annuitization of a couple's individual benefit entitlements ( "step 2"). The latter has been included, as an option, in the new Swedish Premium Pension Scheme established in 2000, an additional mandatory pillar that is fully-funded and located exactly at the border-line between public and private provision.

\subsection{Step 1: Abolishing survivor benefits}

Abolishing survivor pensions implies that net wages and implicit tax rates for married couples are then given by

$$
\begin{aligned}
w_{t}^{m *} & =\left(1-\tau_{t}\left(1-\alpha^{m} \frac{1+\rho_{t+1}}{1+r_{t+1}}\right)\right) W_{t}^{m}=\left(1-\vartheta_{t}^{m *}\right) W_{t}^{m} \\
w_{t}^{f *} & =\left(1-\tau_{t}\left(1-\alpha^{f} \frac{1+\rho_{t+1}}{1+r_{t+1}}\right)\right) W_{t}^{f}=\left(1-\vartheta_{t}^{f *}\right) W_{t}^{f}
\end{aligned}
$$

with

$$
\vartheta_{t}^{f *}<\vartheta_{t}^{m *} \text { because } \alpha^{f}>\alpha^{m}
$$

As long as life expectancies of women are higher than those of men, the implicit tax rates they are faced with would unambiguously move in a direction that should lead to smaller welfare losses in the light of standard estimates regarding the differences in wage elasticities of female vs male labour supply. When assessed by the strict inverse-elasticity rule as stated in Section 3, the solution is not necessarily optimal. But we already said that one should be reluctant to take the simulations and estimates presented here as a precise yardstick for the reforms that are necessary.

Compared to the status quo, a solution of this kind implies financial losses in terms of a given couple's joint benefit entitlements if, according to the distinction introduced in Section 2, the household belongs to "case 1". There would be no

\footnotetext{
${ }^{19}$ As they are not affected by the criticisms raised here, this conclusion need not apply to survivor benefits paid to partners of working age who are prevented from (full) labour-force participation through child-care obligations, at least for a certain period of time.

${ }^{20}$ Since then, survivor benefits in the Swedish public pension scheme are strongly meanstested and, as a rule, only paid for a few months of re-orientation after the contingency arises.
} 
such loss in "case 2" if the different types of benefits off-set each other on a onefor-one basis. Since part of the benefits is often exempted from the reduction, and since reduction rates can be smaller than 100\%, total benefit entitlements would also decrease for case- 2 households if survivor benefits were wiped out. On the other hand, these losses for married couples may effectively indicate that an out-dated type of extra-benefits is abolished, allowing for reductions in the pension system's total budget.

Fully individualizing benefit entitlements for married spouses cannot be achieved without approporiate transition periods. Otherwise, the reforms could annihilate life-cycle planning of married couples, especially of female partners in marriages with a traditional division of labour, at a very late stage. For individuals who have failed to build up sufficient pension entitlements of their own from the very beginning, it would be difficult to make up for that through behavioural changes already when there is still some time to go until retirement. Increasing pension benefits for women whose individual benefit entitlements are small because of parental leaves - a requirement defined by the German Court of Justice in 1992 with respect to any future pension reform - may solve this problem partially but not fully. ${ }^{21}$

A lasting shortcoming of this type of a solution is that the resulting time profile of household income over the periods of joint retirement and survivorhood when the surviving spouse would have to live on his or her own benefit entitlements even if these are rather small - may not at all correspond to a profile that is optimal in terms of the timing of goods consumption and the relevant intertemporal substitution elasticities. For an average couple, the ratio between the sum of both spouses' individual benefit entitlements and the female partner's benefit entitlements that are effective during the period of survivorhood will typically be in the range of 100 to 30 .

This problem is mitigated, but not fully removed, through the new option of continously splitting invidual pension entitlements between the two partners on a 50-to-50 basis that was introduced through the German 2001 pension reform. ${ }^{22}$ The result is a 100-to-50 ratio between benefit entitlements during the subperiods of joint survival and survivorhood, respectively Existing rules for the definition of survivor benefits are mainly based on factors (for the conversion of benefit entitlements of defunct spouses into survivor benefits) between 50 and $60 \%$, additionally exempting part of the survivor's own entitlements from being reduced in return. ${ }^{23}$ In other words, they appear to be targeted at a 100-to-60 (or higher) ratio between benefits accruing in both sub-periods of retirement.

\footnotetext{
${ }^{21}$ The solution suggested in the remainder of this paper is thus open to being augmented by additional changes in the way child-rearing activities are reflected in individual pension entitlements. Proposals of this kind for the German Statutory Pension Scheme are made in Sinn and Werding $(2000 ; 2005)$ and Sinn (2005).

${ }^{22}$ The option is given to couples who married after 1 January 2001, or where both spouses were born after 1 January 1962. At the same time, couples who use it have to give up their entitlements for receiving survivor benefits. So far, this option is used very rarely.

${ }^{23}$ See Fenge et al. (2003, Table 1.15). In Germany, the conversion factor is currently $55 \%$, as was mentioned in Section 2. Until 2000, it was $60 \%$ and, on average, the recent reduction is off-set by higher exemptions for own benefit entitlements of survivors who have raised children.
} 
Apart from that, the "splitting" solution does not appear to be ideal for a number of other reasons. The splitting option is just a small step towards removing the efficiency loss indicated by our results presented in Section 3 as it exactly equalizes implicit tax rates for married females and their husbands. ${ }^{24}$ Also, if it were chosen by a large number of households, part of the potential reductions in pension expenditure through the abolishment of survivor benefits would not materialize because entitlements are typically transferred from males - with higher life-time earnings but lower life expectancy - to their wives. Finally, the simple splitting model may be too rigid in the allocation of the pooled benefit entitlements of a given couple both to the partners and over time. Even a model with variable splitting factors, where spouses can freely choose how much of their benefit entitlements to transfer between them, may not be suited to insure the basic biometrical risks - which of the partners will outlive the other, and by how long? - on which the problem of an adequate provision for survivors ultimately rests.

\subsection{Step 2: Joint annuitization}

A solution that is superior in terms of the flexibility of re-allocating individual benefit entitlements, the insurance of life-expectancy risks, as well as the fiscal costs is given by a joint annuitization of a couple's individual benefit entitlements. The basic idea behind this solution is that, applying actuarial principles and without granting any extra-benefits to survivors, the present value of a married couple's pooled benefit entitlements can be shifted rather freely between the sub-periods of joint retirement and survivorhood. Compared to the case where benefit entitlements are fully individualized, benefits paid out while both partners are still alive would have to be reduced by a certain margin, in order to top up pension benefits for the survivant spouse later on. In both sub-periods, public pensions could then cover an equivalent share of current consumption, first of the couple, then of the single survivor. A solution of this kind can be realized through the simple choice of just one parameter that governs the relevant deductions and top-ups at each point in time. If the pool of risks is large enough, insurance against deviations of individual life expectancies and the actual sequence of deaths from what had to be expected can be easily provided.

The core parameter of the joint-annuitization model is a deduction rate $\delta$ by which benefits actually paid out during joint survival are reduced, thus allowing for higher benefit payments to the survivor later on. The present value of expected total benefits of a given couple has to remain unchanged against a scenario where benefit entitlements are purely individual. This implies that the incentive effects of joint annuitization with respect to each partner's laboursupply decisions are the same as those associated with equations (18) and (19).

${ }^{24} \mathrm{On}$ analogous terms as in equations (18) and (19), the result is now uniformly given by:

$$
w_{t}^{i}=\left(1-\tau_{t}\left(1-\frac{\alpha^{f}+\alpha^{m}}{2} \frac{1+\rho_{t+1}}{1+r_{t+1}}\right)\right) W_{t}^{i}=\left(1-\vartheta_{t}\right) W_{t}^{i}
$$


Within the framework developed in Section 2 - where life expectancies of males and females were taken to be fixed and the time structure was modelled in a rough fashion only - shifting benefit entitlements between the periods of joint survival and survivorhood must satisfy:

$$
\begin{gathered}
p_{t+1}^{m *}+p_{t+1}^{f *}=\left(1+\rho_{t+1}\right) \tau_{t}\left(\alpha^{m} W_{t}^{m} l_{t}^{m}+\alpha^{f} W_{t}^{f} l_{t}^{f}\right) \equiv \\
\equiv\left(1+\rho_{t+1}\right) \tau_{t}[\alpha^{m} \underbrace{(1-\delta)\left(W_{t}^{m} l_{t}^{m}+W_{t}^{f} l_{t}^{f}\right)}_{\text {pooled pension benefits ex deduction }}+ \\
\left.+\left(\alpha^{f}-\alpha^{m}\right)(\underbrace{W_{t}^{f} l_{t}^{f}}_{\text {pension benefit } f}+\underbrace{\frac{\delta \alpha^{m}}{\alpha^{f}-\alpha^{m}}\left(W_{t}^{m} l_{t}^{m}+W_{t}^{f} l_{t}^{f}\right)}_{\text {top-up for the survivor }})\right]
\end{gathered}
$$

By the choice of $\delta$, the increase in pension benefits during the period of survivorhood, $\alpha^{f}-\alpha^{m}$, exactly corresponds to the deduction accepted by the partners during their joint retirement period, $\alpha^{m}$, on present-value terms.

How should $\delta$ be chosen in order to establish the partners' preferred time profile of current benefit payments over the full retirement period? Obviously, this is dependent on the relative size of their individual benefit entitlements (and other sources of old-age income) as well as the actual difference between their contingent life expectancies at the moment of joint annuitization. Based on equation (20), but correcting for the expected length of the relevant sub-periods to estimate the relative size of current ("annual") benefits, we can define the relative level of benefits for the surviving spouse, $\pi$ :

$$
\pi=\frac{1}{1-\delta} \frac{W_{t}^{f} l_{t}^{f}}{W_{t}^{m} l_{t}^{m}+W_{t}^{f} l_{t}^{f}}+\frac{\delta}{1-\delta} \frac{\alpha^{m}}{\alpha^{f}-\alpha^{m}}
$$

Assuming that benefits are jointly annuitized when both partners enter retirement (simultaneously) and calibrating the $\alpha^{i}$ s based on actual values for the average duration of pension benefits paid to men and women in the German Statutory Pension Scheme, ${ }^{25}$ Table 2 shows the results for $\pi$ (ratio of benefits paid to the survivor over benefits paid to the couple during joint survival) as a function of the relative amounts of life-time earnings, hence benefit entitlements, and alternative choices regarding the deduction rate $\delta$. It turns out that relatively small deductions during joint survival are sufficient to ensure a relative level of pension benefits corresponding to what current rules for survivor benefits are meant to provide for $(\pi \geq 60 \%$ being a widely-accepted target level, irrespective of whether the survivant spouse holds own benefit entitlements or not). It should not be surprising that it is the easier to get into this range of $\pi \mathrm{s}$ the higher are individual benefit entitlements of the surviving partner.

\footnotetext{
${ }^{25}$ In West-Germany, the corresponding value for males is 14.6 years, for females 18.8 years (see Verband Deutscher Rentenversicherungsträger, 2004).
} 
Table 2: Relative level of benefits for survivors $(\pi)$

\begin{tabular}{|c|c|c|c|c|c|}
\hline \multirow[b]{2}{*}{$W^{f} l^{f} / W^{m} l^{m}$} & \multicolumn{5}{|c|}{$\overline{\delta \delta=}$} \\
\hline & 0.025 & 0.05 & 0.075 & 0.1 & 0.15 \\
\hline 0.00 & $8.9 \%$ & $18.3 \%$ & $28.2 \%$ & $38.6 \%$ & $61.3 \%$ \\
\hline 0.25 & $29.4 \%$ & $39.3 \%$ & $49.8 \%$ & $60.8 \%$ & $84.9 \%$ \\
\hline 0.50 & $43.1 \%$ & $53.4 \%$ & $64.2 \%$ & $75.7 \%$ & $100.6 \%$ \\
\hline 0.75 & $52.9 \%$ & $63.4 \%$ & $74.5 \%$ & $86.2 \%$ & $111.8 \%$ \\
\hline 1.00 & $60.2 \%$ & $70.9 \%$ & $82.2 \%$ & $94.2 \%$ & $120.2 \%$ \\
\hline
\end{tabular}

In reality, there are a number of additional complications for the solution sketched here to be workable which are not covered by the simple model developed in Section 2. First, the partners could retire at different points in time. Basically, (outstanding) pension entitlements of a married couple can be jointly annuitized at any point in time during their retirement phase. The effect of $\delta$ becomes weaker the shorter contingent life expectancy of the partner who is likely to die first. But the re-assessment of benefits can be easily done when the first of the spouses enters retirement as well as when the second one retires.

Second, life expectancy of females is higher than that of males in all industrialized countries, and married women are typically younger than their husbands almost everywhere. Still, in individual cases it is perfectly possible that it is the man who lives longer than his wife. If joint annuitization were only made in the light of the opposite case, this could lead to an over-provision for the surviving husband and a sub-optimal structure of consumption over the full retirement period. But if mortality rates are known for both partners, the choice of $\delta$ can be translated into a choice of the relative level of benefits, $\pi$, or a preferred time profile of paying out $p_{t+1}^{m *}+p_{t+1}^{f *}$ which should then be considered the true objective of insurance, irrespective of the actual sequence of deaths.

Third, the retirement period also has a certain length and time structure, a feature that is captured by our model only in a rough fashion. In reality, the question arises which discount rate should be used for assessing deductions and top-ups: the capital-market rate of interest (adjusted for a risk premium associated with an insurance of longevity risks) or, more in line with how a pay-as-you-go scheme is actually operated, the pension scheme's internal rate of return? By actuarial standards, the first of these options is certainly more appropriate. Also, it is the only solution that is really neutral regarding the choice of the timing of benefit payments. On the other hand, turning regular old-age pensions into top-ups for survivors at a market rate of interest implies that, when aggregated over time, total pension expenditure increases since topups paid during the survivorhood period are higher than earlier deductions by a rate that exceeds the fundamental growth rate of the pension budget.

It was already mentioned that, probably following a longer transition period, abolishing traditional survivor benefits should definitely reduce total pension ex- 
penditure. If, in addition, paying out part of the individual benefit entitlements of married spouses were postponed until the period of survivorhood of just one partner, there is a further, transitory reduction in expenditure which, on present-value terms, is exactly off-set by higher expenditure later on. It would therefore appear a natural solution to channel these transitory reductions into a special "survivors' reserve" (not into transitory reductions of contribution rates or transitory increases in benefit levels) in order to actually pre-fund for the benefit entitlements that are simply becoming effective with a delay. If this is how the scheme were operated, jointly annuitizing pension benefit entitlements of married couples at a discount rate derived from the capital-market rate of interest should not cause any budgetary problems.

\section{Conclusion}

An aspect that has not been covered yet is whether public intervention is needed at all with respect to providing for survivors. With any given time profile of benefit payments, providing for a partner with lower benefit entitlements who is most likely to outlive the other can in principle also be accomplished through making private savings or buying appropriate life-insurance cover. But "framing" these kinds of decisions through some sort of public provision, linked to a mandatory pension system, may nonetheless be to the advantage of many individuals, especially if this can be arranged for in a simple way involving relatively low transaction costs. ${ }^{26}$ To the extent that this contributes to establishing consumption profiles with higher utility levels, and helps avoiding cases of under-provision, offering such a scheme could lead to genuine welfare gains.

In the first place, however, the problem we have been dealing with in this paper is not a matter of adequate provisions and other distributional concerns. Abolishing traditional survivor benefits and replacing them with a flexible approach to jointly annuitizing individual benefit entitlements for married couples is mainly meant to solve the incentive problem worked out in Sections 2 and 3 . It is unclear whether the proposal would perfectly solve this problem as it reduces the level of implicit tax rates for women below the one for men, but not necessarily to the extent that might be required considering the enormous differences in their wage elasticities of labour supply. On the other hand, we would like to repeat that the estimates we have referred to should not be taken to offer a precise measure for the size of the corrections needed. A reform that strengthens the role of individual, contributory benefit entitlements, combined with a joint annuitization scheme for (married) couples, will in any case reduce the inefficiency to which we have been pointing.

\footnotetext{
${ }^{26}$ For instance, the benefit administration could go as far as defining a value for $\delta$ that establishes a 100-to-60 ratio for $\pi$ based on any two spouses' individual benefit entitlements. The two partners could then over-rule this preliminary choice through a joint decision provided that they are able to demonstrate that the resulting time profile of old-age income will not give rise to other benefit entitlements.
} 


\section{LITERATURE}

Ashenfelter, Orley C. and James J. Heckman (1974), "The estimation of income and substitution effects in a model of family labor supply", Econometrica $42,73-85$.

Atkinson, Anthony B. and Joseph E. Stiglitz (1980), Lectures on Public Economics, London et al.: McGraw-Hill.

Blau, David H. (1997), "Social Security and the labour supply of older married couples", Labour Economics 4, 373-418.

Blundell, Richard and Thomas MaCurdy (1999), "Labor supply: a review of alternative approaches", in: Orley C. Ashenfelter and David Card (eds.), Handbook of Labor Economics, Vol. 3A, Amsterdam et al.: North-Holland, 1559-1695.

Bowen, William G. and T. Aldrich Finegan (1969), The Economics of Labor Force Participation, Princeton NJ: Princeton University Press.

Breyer, Friedrich (1989), "On the intergenerational Pareto efficiency of pay-asyou-go financed pension systems", Journal of Institutional and Theoretical Economics 145, 643-658.

Browning, Martin, François Bourguignon, Pierre-André Chiappori and Valérie Lechène (1994), "Income and outcomes: A structural model of intrahousehold allocation", Journal of Political Economy 102, 1067-1096.

Buslei, Hermann and Viktor Steiner (1999), Beschäftigungseffekte von Lohnsubventionen im Niedriglohnbereich, Baden-Baden: Nomos.

Chiappori, Pierre-André (1992), "Collective labor supply and welfare", Journal of Political Economy 100, 437-467.

Fenge, Robert (1995), "Pareto-efficiency of the pay-as-you-go pension system with intragenerational fairness", Finanzarchiv 52, 357-364.

Fenge, Robert, Andrea Gebauer, Christian Holzner, Volker Meier and Martin Werding (2003), Alterssicherungssysteme im internationalen Vergleich: Finanzierung, Leistungen, Besteuerung, ifo Beiträge zur Wirtschaftsforschung, Vol. 10, München: Ifo Institute.

Fenge, Robert, Silke Uebelmesser and Martin Werding (2002), "Second-best properties of implicit social security taxes: Theory and evidence", CES-ifo Working Paper No. 743.

Fenge, Robert, Silke Uebelmesser and Martin Werding (2005), "On the optimal timing of implicit social security taxes", mimeo. 
Fenge, Robert and Martin Werding (2003), "Ageing and fiscal imbalances across generations: Concepts of measurement", CESifo Working Paper No. 842 .

Fenge, Robert and Martin Werding (2004), "Ageing and the tax implied in public pension schemes: Simulations for selected OECD countries", Fiscal Studies 25, 159-200.

Franz, Wolfgang (1985), "An econometric analysis of female work participation, education, and fertility: Theory and empirical evidence for the Federal Republic of Germany", Journal of Labour Economics 3, S218-S234.

Frerich, Johannes and Martin Frey (1993), Handbuch der Geschichte der Sozialpolitik in Deutschland. Vol. 1: Von der vorindustriellen Zeit bis zum Ende des Dritten Reiches, München and Wien: Oldenbourg.

Heckman, James J. (1979), "Sample selection bias as a specification error", Econometrica 47, 153-161.

Kaltenborn, Bruno (2000), Reformkonzepte für die Sozialhilfe: Finanzbedarf und Arbeitsmarkteffekte, Baden-Baden: Nomos.

Killingsworth, Mark R. (1983), Labor Supply, Cambridge UK: Cambridge University Press.

Killingsworth, Mark R. and James J. Heckman (1986), "Female labor supply: A survey", in: Orley C. Ashenfelter and Richard Layard (eds.), Handbook of Labor Economics, Vol. 1, Amsterdam et al.: North-Holland, 103-204.

Ott, Notburga (1992), Intrafamily Bargaining and Household Decisions, Berlin et al.: Springer.

Sandmo, Agnar (1974), "A note on the structure of optimal taxation", American Economic Review 64, 701-706.

Sandmo, Agnar (1987), "A reinterpretation of elasticity formulae in optimum tax theory", Economica 54, 89-96.

Sinn, Hans-Werner (2000), "Why a funded system is useful and why it is not useful", International Tax and Public Finance 7, 389-410.

Sinn, Hans-Werner (2005), "Europe's demographic deficit: A plea for a child pension system", De Economist 153, 1-45.

Sinn, Hans-Werner and Martin Werding (2000), "Rentenniveausenkung und Teilkapitaldeckung: ifo Empfehlungen zur Konsolidierung des Umlageverfahrens", ifo Schnelldienst 53, Issue 18/2000, 12-25.

Sinn, Hans-Werner and Martin Werding (2005), "Kinderrente und Vorsorgepflicht: Der ifo Vorschlag zur Lösung der demographischen Krise des Rentensystems", ifo Schnelldienst 58 (in preparation). 
Strøm, Steinar and Gerhard Wagenhals (1991), "Female labour supply in the Federal Republic", Jahrbücher für Nationalökonomie und Statistik 208, $575-595$.

Steiner, Viktor and Katharina Wrohlich (2004), "Household taxation, income splitting and labour supply incentives: A microsimulation study for Germany", CESifo Economic Studies 50, 541-568.

Thum, Marcel and Jakob von Weizsäcker (2000), "Implizite Einkommensteuer als Messlatte für die aktuellen Rentenreformvorschläge", Perspektiven der Wirtschaftspolitik 1, 453-468.

Tobin, James (1958), "Estimation of relationship for limited dependent variables", Econometrica 26, 24-36.

Untiedt, Gerhard (1992), Das Erwerbsverhalten verheirateter Frauen in der Bundesrepublik Deutschland, Heidelberg: Physica.

Verband Deutscher Rentenversicherungsträger (2004), Rentenversicherung in Zeitreihen: Ausgabe 2004, Frankfurt/Main: VDR.

Werding, Martin and Anita Kaltschütz (2005), Modellrechnungen zur langfristigen Tragfähigkeit der öffentlichen Finanzen, ifo Beiträge zur Wirtschaftsforschung, Vol. 17, München: Ifo Institute.

Zameck, Walburga von (1997), Ökonomische Theorie der Frau: Eine mikroökonomische Analyse von Markt- und Nichtmarktentscheidungen, Berlin: Duncker \& Humblot. 


\title{
CESifo Working Paper Series
}

\author{
(for full list see www.cesifo-group.de)
}

1533 Roberta Colavecchio, Declan Curran and Michael Funke, Drifting Together or Falling Apart? The Empirics of Regional Economic Growth in Post-Unification Germany, September 2005

1534 Kai A. Konrad and Stergios Skaperdas, Succession Rules and Leadership Rents, September 2005

1535 Robert Dur and Amihai Glazer, The Desire for Impact, September 2005

1536 Wolfgang Buchholz and Wolfgang Peters, Justifying the Lindahl Solution as an Outcome of Fair Cooperation, September 2005

1537 Pieter A. Gautier, Coen N. Teulings and Aico van Vuuren, On-the-Job Search and Sorting, September 2005

1538 Leif Danziger, Output Effects of Inflation with Fixed Price- and Quantity-Adjustment Costs, September 2005

1539 Gerhard Glomm, Juergen Jung, Changmin Lee and Chung Tran, Public Pensions and Capital Accumulation: The Case of Brazil, September 2005

1540 Yvonne Adema, Lex Meijdam and Harrie A. A. Verbon, The International Spillover Effects of Pension Reform, September 2005

1541 Richard Disney, Household Saving Rates and the Design of Social Security Programmes: Evidence from a Country Panel, September 2005

1542 David Dorn and Alfonso Sousa-Poza, Early Retirement: Free Choice or Forced Decision?, September 2005

1543 Clara Graziano and Annalisa Luporini, Ownership Concentration, Monitoring and Optimal Board Structure, September 2005

1544 Panu Poutvaara, Social Security Incentives, Human Capital Investment and Mobility of Labor, September 2005

1545 Kjell Erik Lommerud, Frode Meland and Odd Rune Straume, Can Deunionization Lead to International Outsourcing?, September 2005

1546 Robert Inklaar, Richard Jong-A-Pin and Jakob de Haan, Trade and Business Cycle Synchronization in OECD Countries: A Re-examination, September 2005

1547 Randall K. Filer and Marjorie Honig, Endogenous Pensions and Retirement Behavior, September 2005 
1548 M. Hashem Pesaran, Til Schuermann and Bjoern-Jakob Treutler, Global Business Cycles and Credit Risk, September 2005

1549 Ruediger Pethig, Nonlinear Production, Abatement, Pollution and Materials Balance Reconsidered, September 2005

1550 Antonis Adam and Thomas Moutos, Turkish Delight for Some, Cold Turkey for Others?: The Effects of the EU-Turkey Customs Union, September 2005

1551 Peter Birch Sørensen, Dual Income Taxation: Why and how?, September 2005

1552 Kurt R. Brekke, Robert Nuscheler and Odd Rune Straume, Gatekeeping in Health Care, September 2005

1553 Maarten Bosker, Steven Brakman, Harry Garretsen and Marc Schramm, Looking for Multiple Equilibria when Geography Matters: German City Growth and the WWII Shock, September 2005

1554 Paul W. J. de Bijl, Structural Separation and Access in Telecommunications Markets, September 2005

1555 Ueli Grob and Stefan C. Wolter, Demographic Change and Public Education Spending: A Conflict between Young and Old?, October 2005

1556 Alberto Alesina and Guido Tabellini, Why is Fiscal Policy often Procyclical?, October 2005

1557 Piotr Wdowinski, Financial Markets and Economic Growth in Poland: Simulations with an Econometric Model, October 2005

1558 Peter Egger, Mario Larch, Michael Pfaffermayr and Janette Walde, Small Sample Properties of Maximum Likelihood Versus Generalized Method of Moments Based Tests for Spatially Autocorrelated Errors, October 2005

1559 Marie-Laure Breuillé and Robert J. Gary-Bobo, Sharing Budgetary Austerity under Free Mobility and Asymmetric Information: An Optimal Regulation Approach to Fiscal Federalism, October 2005

1560 Robert Dur and Amihai Glazer, Subsidizing Enjoyable Education, October 2005

1561 Carlo Altavilla and Paul De Grauwe, Non-Linearities in the Relation between the Exchange Rate and its Fundamentals, October 2005

1562 Josef Falkinger and Volker Grossmann, Distribution of Natural Resources, Entrepreneurship, and Economic Development: Growth Dynamics with Two Elites, October 2005

$1563 \mathrm{Yu}-\mathrm{Fu}$ Chen and Michael Funke, Product Market Competition, Investment and Employment-Abundant versus Job-Poor Growth: A Real Options Perspective, October 2005 
1564 Kai A. Konrad and Dan Kovenock, Equilibrium and Efficiency in the Tug-of-War, October 2005

1565 Joerg Breitung and M. Hashem Pesaran, Unit Roots and Cointegration in Panels, October 2005

1566 Steven Brakman, Harry Garretsen and Marc Schramm, Putting New Economic Geography to the Test: Free-ness of Trade and Agglomeration in the EU Regions, October 2005

1567 Robert Haveman, Karen Holden, Barbara Wolfe and Andrei Romanov, Assessing the Maintenance of Savings Sufficiency Over the First Decade of Retirement, October 2005

1568 Hans Fehr and Christian Habermann, Risk Sharing and Efficiency Implications of Progressive Pension Arrangements, October 2005

1569 Jovan Žamac, Pension Design when Fertility Fluctuates: The Role of Capital Mobility and Education Financing, October 2005

1570 Piotr Wdowinski and Aneta Zglinska-Pietrzak, The Warsaw Stock Exchange Index WIG: Modelling and Forecasting, October 2005

1571 J. Ignacio Conde-Ruiz, Vincenzo Galasso and Paola Profeta, Early Retirement and Social Security: A Long Term Perspective, October 2005

1572 Johannes Binswanger, Risk Management of Pension Systems from the Perspective of Loss Aversion, October 2005

1573 Geir B. Asheim, Wolfgang Buchholz, John M. Hartwick, Tapan Mitra and Cees Withagen, Constant Savings Rates and Quasi-Arithmetic Population Growth under Exhaustible Resource Constraints, October 2005

1574 Christian Hagist, Norbert Klusen, Andreas Plate and Bernd Raffelhueschen, Social Health Insurance - the Major Driver of Unsustainable Fiscal Policy?, October 2005

1575 Roland Hodler and Kurt Schmidheiny, How Fiscal Decentralization Flattens Progressive Taxes, October 2005

1576 George W. Evans, Seppo Honkapohja and Noah Williams, Generalized Stochastic Gradient Learning, October 2005

1577 Torben M. Andersen, Social Security and Longevity, October 2005

1578 Kai A. Konrad and Stergios Skaperdas, The Market for Protection and the Origin of the State, October 2005

1579 Jan K. Brueckner and Stuart S. Rosenthal, Gentrification and Neighborhood Housing Cycles: Will America’s Future Downtowns be Rich?, October 2005 
1580 Elke J. Jahn and Wolfgang Ochel, Contracting Out Temporary Help Services in Germany, November 2005

1581 Astri Muren and Sten Nyberg, Young Liberals and Old Conservatives - Inequality, Mobility and Redistribution, November 2005

1582 Volker Nitsch, State Visits and International Trade, November 2005

1583 Alessandra Casella, Thomas Palfrey and Raymond Riezman, Minorities and Storable Votes, November 2005

1584 Sascha O. Becker, Introducing Time-to-Educate in a Job Search Model, November 2005

1585 Christos Kotsogiannis and Robert Schwager, On the Incentives to Experiment in Federations, November 2005

1586 Søren Bo Nielsen, Pascalis Raimondos-Møller and Guttorm Schjelderup, Centralized vs. De-centralized Multinationals and Taxes, November 2005

1587 Jan-Egbert Sturm and Barry Williams, What Determines Differences in Foreign Bank Efficiency? Australian Evidence, November 2005

1588 Steven Brakman and Charles van Marrewijk, Transfers, Non-Traded Goods, and Unemployment: An Analysis of the Keynes - Ohlin Debate, November 2005

1589 Kazuo Ogawa, Elmer Sterken and Ichiro Tokutsu, Bank Control and the Number of Bank Relations of Japanese Firms, November 2005

1590 Bruno Parigi and Loriana Pelizzon, Diversification and Ownership Concentration, November 2005

1591 Claude Crampes, Carole Haritchabalet and Bruno Jullien, Advertising, Competition and Entry in Media Industries, November 2005

1592 Johannes Becker and Clemens Fuest, Optimal Tax Policy when Firms are Internationally Mobile, November 2005

1593 Jim Malley, Apostolis Philippopoulos and Ulrich Woitek, Electoral Uncertainty, Fiscal Policy and Macroeconomic Fluctuations, November 2005

1594 Assar Lindbeck, Sustainable Social Spending, November 2005

1595 Hartmut Egger and Udo Kreickemeier, International Fragmentation: Boon or Bane for Domestic Employment?, November 2005

1596 Martin Werding, Survivor Benefits and the Gender Tax Gap in Public Pension Schemes: Observations from Germany, November 2005 